\title{
Influence of Coal Industry Enterprises on Biodiversity (on the Example of Formicidae)
}

\author{
Svetlana Blinova, ${ }^{1, *}$, and Tatiana Dobrydina ${ }^{2}$ \\ ${ }^{1}$ Kemerovo State University, Department of Ecology and Nature Management, 650000, 6 Krasnaya \\ st., Kemerovo, Russian Federation \\ ${ }^{2}$ Kemerovo State University, Department of Foreign Languages in Professional Communication, \\ 650000, 6 Krasnaya st., Kemerovo, Russian Federation
}

\begin{abstract}
The fauna, the population density and the types of ants' nests on the territory affected by the coal industry have been studied. It has been found that the level of environmental contamination influences all the indicators: the minimum indices of density, 1-2 species of ants and only underground nests near the pollution sources. On the contrary, in the areas with a weak influence of coal enterprises, 9 species with a maximum density of up to 15.2 nests $/ \mathrm{m}^{2}$ have been observed with predominance of nests in the form of earthen mounds. Lasius niger are the most resistant to pollution, while the Myrmica do not stand such an impact.
\end{abstract}

\section{Introduction}

The constantly increasing anthropogenic influence on natural ecosystems which reduces their biodiversity, and, therefore, their stability, is one of the current problems. The study of the green areas of industrial cities, including parks, squares and lawns is becoming particularly relevant. One of the indicators of the stability of such sites is insectherpetobionts which react sensitively to the changes in environmental conditions. In the opinion of a number of authors [1-2], ants are an informative component of the biocenosis and able to serve as indicators of certain habitat conditions because of their abundance, high species diversity, complex structure of the formed communities, permanent habitation on the same site. According to the observations [3-4], industrial pollution leads to limiting the number of species, reducing the density of nests and the number of individuals in them. Intensive industrial development leads to reducing the number of anthills Formica rufa by $66.5 \%$ over 5 years [5].

In the Czech Republic, in places where brown coal is extracted, the same species of ants as in natural cenoses have been observed. But the mountain species Formica lemani and Manica rubida have been found only on dumps and not in natural cenoses. In contrast, the nests of Myrmica rubra have been registered only in natural cenoses [6]. In Italy, the quantity of cold-loving and forest species and the representation of the individual genera Formicidae change in the species richness depending on the age of the dumps [7].

\footnotetext{
* Corresponding author: $\underline{\text { sv blinova@mail.ru }}$
} 
However, urban conditions are more severe for the life of ants: only some species settle and survive there [8]. Therefore, ant complexes in urban areas are characterized by poor species composition and the presence of 1-2 dominant species [8-11].

It is shown that ants' communities are sensitive to the environmental consequences of land use in Brazil's mangrove systems [12]. In Japan, to assess the changes in soil in the cities, it is proposed to use Messor aciculatus [11]. The example of Italy shows that the indicators of species richness and abundance of ants can act as bioindicators of the degree of restoration/disturbance of various biotopes [13]. The other authors suggest using a species composition to control the degree of development of agrocenoses. At the same time, it is pointed out that there should be its own set of indicator species for each locality [14].

Some species of ants can act as indicators of land restoration after mining [7]. Our studies [15] of Formicidae have shown the possibility of judging the degree of influence of industrial production by the reaction of ants. Therefore, the purpose of this work is to analyze the impact of coal industry enterprises on ants on grass-cereals meadows located at different distances from the sources of impact.

\section{Materials and Methods}

The studies were conducted from 1996 to 2013 in Prokopyevsk (Pr) located on the territory of the Kuznetsk coal basin (Kemerovo Region, Russia). Coal mining is the main economic activity in the city with $79 \%$ deep mining and $21 \%$ surface mining. During the study, the total release and emission of pollutants into the city environment averages about $61.127 \pm$ 12.75 thousand tons. The coal industry and municipal coal-fired boiler houses make the main contribution to the city air pollution. Dust, soot, carbon monoxide, phenols, and sulfur oxide (IV) have been found in the air within a radius of $2 \mathrm{~km}$ from the mines. Their concentration decreases in some father distance from the emission sources but the average concentration in the $2 \mathrm{~km}$ area is 1.5-2 times lower than in the 500-m radius area.

At the beginning of the study, within the city, there operated 16 coal enterprises (not taking into account coal-fired boiler houses); since 2010, the number of mines has reduced gradually. Currently, there is one mine there.

The collection of all the material was carried out using standard myrmecological methods: 5 areas were allocated at different distances from the coal enterprises, 5-10 test sites $\left(5 * 5 \mathrm{~m}^{2}\right.$ in size) were laid on the area (table 1$)$. An area with a grass-cereals meadow, located opposite the wind rose, $30 \mathrm{~km}$ from the city, was used for monitoring.

Table 1. Characteristics of the studied areas.

\begin{tabular}{|c|c|c|c|c|}
\hline $\begin{array}{c}\text { Area } \\
\text { name }\end{array}$ & $\begin{array}{c}\text { Distance from } \\
\text { source of } \\
\text { emission, } \mathbf{k m}\end{array}$ & $\begin{array}{c}\text { Pollution } \\
\text { level }\end{array}$ & $\begin{array}{c}\text { Projective } \\
\text { grass cover, } \\
\mathbf{\%}\end{array}$ & Notes \\
\hline $\operatorname{Pr} 1$ & $0-0.5$ & high & 40 & $\begin{array}{c}50 \% \text { of the territory } \\
\text { covered with a layer } \\
\text { of } 5 \text { cm of coal dust }\end{array}$ \\
\hline $\operatorname{Pr} 2$ & $0.5-1$ & high & 50 & $\begin{array}{c}\text { Technological dumps } \\
\text { formed in 1960-1980 }\end{array}$ \\
\hline $\operatorname{Pr} 3$ & 1.5 & average & $50-70$ & \\
\hline $\operatorname{Pr} 4$ & $5-5.5$ & average & 85 & \\
\hline $\operatorname{Pr} 5$ & 10 & low & 95 & \\
\hline $\operatorname{Pr} \mathrm{M}$ & 45 & low & $90-95$ & Monitoring \\
\hline
\end{tabular}


The areas were inspected; if necessary, the soil was scrabbled. When finding a nest, no work was conducted in diameter $0.2-0.25 \mathrm{~m}$ : this is the conventional territory occupied by one family. All quantitative material was processed by statistical methods in the Excel program.

\section{Results and discussion}

Within the investigated territory, 10 species of ants belonging to 5 genera of two subfamilies have been found: Myrmica rubra L., M. scabrinodis Nyl., M. schencki Emery, Tetramorium caespitum L., Formica fusca L., F. cunicularia Latr., F. polyctena Forst., F. rufa L., Lasius flavus Fabr., L. niger L. At the same time, the distribution of the detected species and genera within the investigated territory is uneven. So, in the area with a high pollution level, nests of ants of the genus Lasius predominate. With distance from the coal mining enterprises, the number of nests of the genus Myrmica and Formica increases.

\subsection{Species composition and density of nests}

In general, within the investigated territory, ants are distributed unevenly: the smallest number of species and the lowest density of nests have been observed in close vicinity to the coal dust sources. With distance, these indicators increase. However, in the monitoring area, in the city, they are somewhat lower than in the areas with a low degree of the coal industry impact (Fig. 1).

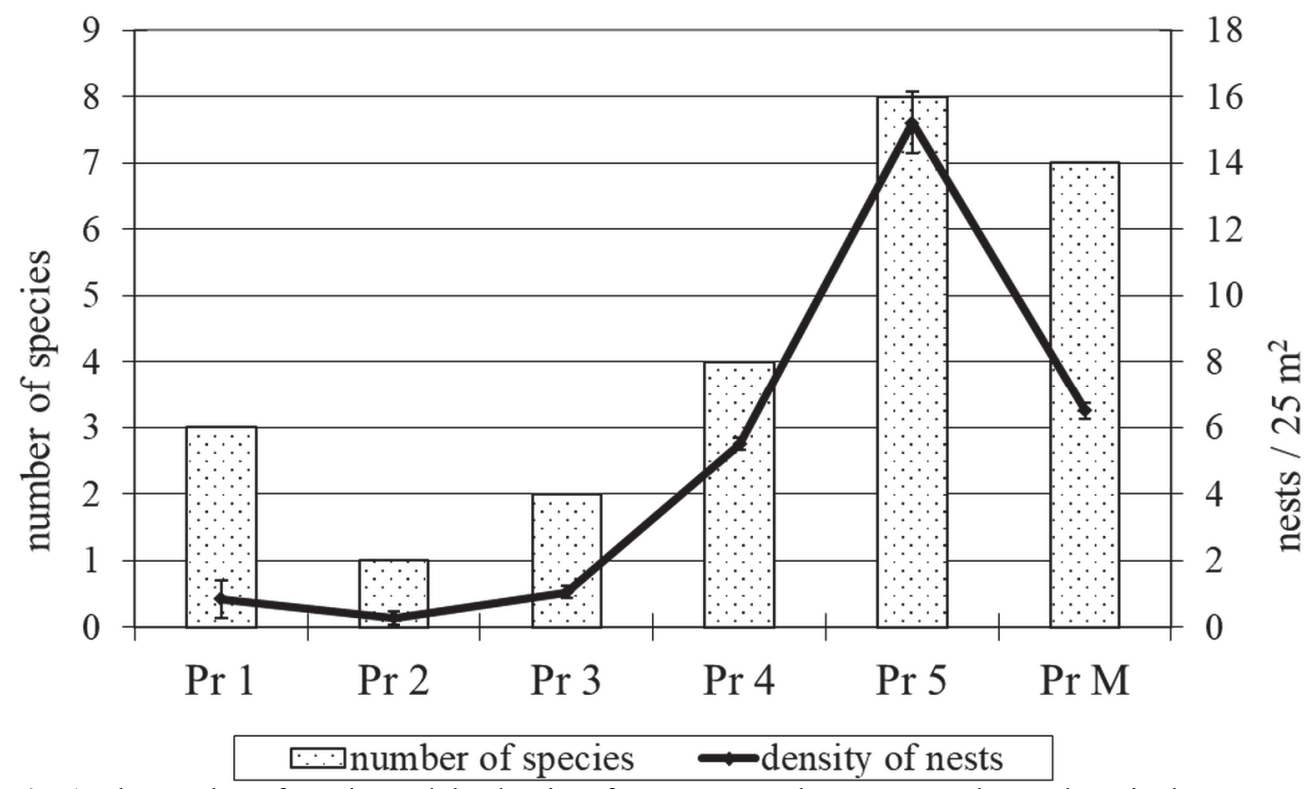

Fig. 1. The number of species and the density of ants nests on the grass-cereals meadows in the area affected by the coal industry (monitoring and average). The explanation of the areas is in Table 1.

In the years 2006-2010, amid the coal production breakdown, enlarging species composition and increasing density of nests were recorded, primarily in the mine areas (up to 3 species and up to 4 nests $/ 25 \mathrm{~m}^{2}$ in some areas). However, in the most polluted areas with coal dust and crumbs, there was not a single nest.

After the subsequent reclamation in 10-15 years, a mono-species settlement of L. niger is observed in the vicinity of mines, mine workings and concentrating mills. 
There are no nests of ants at the 25-30 years old mine dumps which have never had reclamations (Pr 2). Ants make settlements on the dumps only 35-40 years after the dumps' formation. In this case, only the mono-species settlements of L. niger were recorded for the first 5 years. Thus, on the dumps formed 35-40 years ago, the density of the settlement reached 0.3 nests $/ 25 \mathrm{~m}^{2}$, at $45-50$ years old dumps there were 0.4 nests $/ 25 \mathrm{~m}^{2}$.

Ants of the genus Lasius reach the greatest species diversity and density of settlement in the area with high pollution. In this case, the number of nests increases (from 0.1 to 1.5 nests $/ 25 \mathrm{~m}^{2}$ ) with a large number of small stones (about $15 \mathrm{~cm}$ in diameter) or a distance from shafts (on average, $200 \mathrm{~m}$ ), excavations (for example, near administrative buildings). The distribution of species of the genus Lasius appeared to correlate with the volumes of industrial emissions: the number of species increases with the decrease in the coal industry impact $(r=-0.51$ at $p<0.05)$. Thus, nests of $L$. niger have been found in all the areas. With the decrease in the volume of emissions near the mines, the nests of L. flavus have also been recorded.

In contrast, the number of species of the genera Myrmica, Tetramorium and Formica increases with the distance from coal mining enterprises; the quantity of these genera nests increases, reaching the maximum in areas with a low level of exposure. For example, there are $37.2 \pm 0.7 \%$ in area $\operatorname{Pr} 5$, and $42.9 \pm 0.9 \%$ Formica nests in the monitoring area $\operatorname{Pr} \mathrm{M}$. The representatives of the genus Formica are not found near the industrial enterprises (within a radius of $4.5 \mathrm{~km}$ ). The exception is F. rufa, an anthill of which has been found near the shafts of the administrative buildings of one of the investigated mines. At the same time, only the nests of the subgenus Serviformica - F. fusca and F. cunicularia have been recorded in areas with an average level of pollution.

Ants of the Myrmica family have been registered only in the area with a low level of impact of coal industry enterprises. However, the nests of M. rubra and M. schencki are found only in the city. Such observations coincide with the results of our similar work done in the areas influenced by the cement and lead-zinc industries [15].

\subsection{Characteristics of the nest-building}

The study has detected four main types of nests: underground, with an earthen mound, with a plant dome and under a stone. The analysis of the dependence of the nest types on the distance to the source of emissions has showen that the quantity of nests located under the stones depends only on the presence of small stones on the area and does not relate to the contamination. On the contrary, the quantity of nests of the other types varies depending on the distance to the coal industry enterprises. So, in the area with the greatest pollution, ants settle only in underground nests without land structures. At a distance from the sources of emissions, the number of capsule nests (ground mounds and mounds with a plant dome) increases. An increase in the linear dimensions of the nesting mounds of L. niger ants has also been observed (Fig. 2). It has been noted that the height of the nesting hillock is directly proportional to the distance from the mine faces and descents into the mine $(\mathrm{r}=$ 0.67 with $\mathrm{p}<0.05$ ). In the immediate vicinity of the coal mining enterprises, only underground nests have been found. At a distance of $1.5 \mathrm{~km}$ (area $\operatorname{Pr} 3$ ), their quantity decreases to $90.3 \pm 11.5 \%$. The minimum of underground nests has been registered in the monitoring area: $32.3 \pm 12.6 \%$. In contrast, about $65 \%$ of all the nests with ground domes have been observed in the monitoring area and in the area with a weak level of influence. 


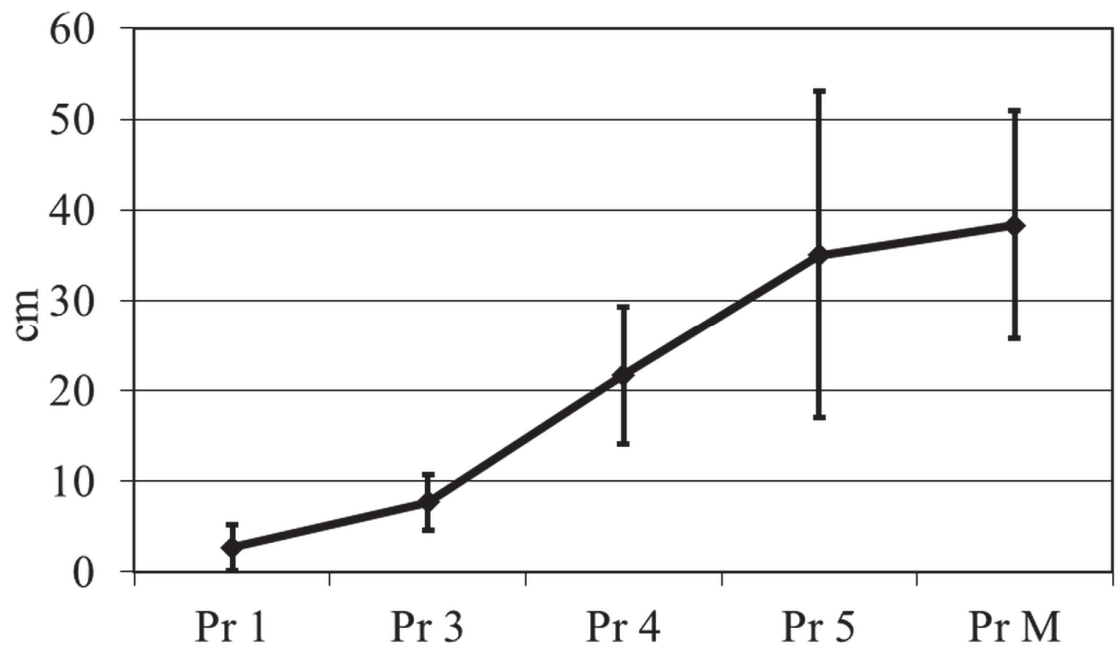

Fig. 2. The average height of the earthen mound depending on the distance to the coal dust sources. The explanation of the areas is in Table 1.

According to our observations, L. niger can use coal crumb as a breeding material only in mixture with the soil. The only nest of T. caespitum, located directly in the coal crumb, was observed. However, in the following years, even with a decrease in the impact, such nests have not been found.

\section{Conclusion}

Thus, ants exhibit a quasi-adaptive type of reaction to the pollution by coal enterprises: a reduction in the species composition and in density of the ants' nests has been observed near the coal enterprises. With distance from the pollution sources, all the parameters under the study increase first, but then again decrease to average values. The reduction of the total volume of mine emissions that occurred due to the closure of several mines may have influenced the increase in the species and density of the ants' settlement in the investigated areas.

The ants of the genus Lasius, occurring at any level of pollution by industrial emissions, are the most resistant to anthropogenic impact; they numerically dominate in all the areas studied in the city.

Ants of the genus Myrmica do not withstand the influence of solid industrial emissions: they are found only in a relatively clean area.

In the area of coal dust impact on the biotopes, underground nests without ground structures have been observed mainly. Most of the nests found in the monitoring area are in the form of earthen mounds or hillocks of plant residues.

The number of species, the density of nests and the numerical ratios of various types of ants' nests can act as indicators of the coal industry impact on the environment, allowing the rapid identification of a decrease in biodiversity and, consequently, a decrease in the stability of the ecosystem as a whole.

\section{References}

1. T. Puszkar, Mem. zool. 29, 129-142 (1978). 
2. J. D. Majer, Env. Man. 7:4, 375-383 (1983).

3. J.M. Petal, Mem. zool. 29, 99-108 (1978).

4. J. M. Petal, Pol. Ecol. Stud. (PRL) 6:4, 665-672 (1980).

5. W. T. Szczepanski, T. Podkowka, Sylwan. 127:5, 35-44 (1983).

6. M. Holec, J. Frouz, Pedobiologia. 49:4, 345-357 (2005).

7. L. Ottonetti, L. Tucci, G.. Santini Restoration Ecology. 14, № 1, 60-66 (2006).

8. K. Vepsalainen, B. Pisarski, Animals in urban environment. Proceedings of the Symp. on the occasion of the 60-th anniversary of the Institute Zool. of the Polish Academy of Sciences. 155-168 (1982).

9. B. Pisarski, W. Czechowski, Mem. Zool. 29, 109-128 (1978).

10. J. D. Majer, K. R. Brown, J. R .Soc. West. Aust. 69, 13-17 (1987).

11. T. Yamaguchi, Entomol. Sci. 8:1, 17-25 (2005).

12. J. H. Delabie, V. R. Paim, I. C. Do Nascimento, S. Campiolo, C. S. Neotrop. Entomol. 35:5, 602-615 (2006).

13. L. Ottonetti, L. Tucci, G., Redia LXXXVII, 199-202 (2004)

14. C. Castracani, A. Piotti, D. A. Grasso Redia. XC, 67-70 (2007).

15. S.V. Blinova, Russian Journal of Ecology. 39:2, 148-150(2008). 